figures, this new and thoroughly revised edition is as valuable as its predecessors. It should always be available as a guide to those responsible for the initial treatment of the more common limb fractures. By reading it they will be taking one step further towards acquiring one of the most valuable and ancient of surgical skillsthe closed treatment of a fracture.

\section{The Control of Disease in the Tropics}

T. H. Davey; W. P. H. Lightbody. Second edition. Pp. xii +422 , with 82 illustrations. London: H. K. Lewis. 1961. f,2 7s. 6d.

The second edition of this book, which is 14 pages longer than its predecessor, includes a number of important new chapters, such as those on poliomyelitis and health education, and some of the existing chapters have been enlarged.

The arrangement of the chapters is rational, there are over 80 useful drawings and diagrams, and there is a valuable Appendix.

Throughout this book the reader is made conscious of the part played by poverty, ignorance and poor living conditions in the genesis of disease in the Tropics, and the authors rightly stress the importance of gaining the active cooperation of the people themselves in creating a healthier environment.

Although the treatment of the individual can be considered a practical aspect of the control of disease in a community, the authors would be well advised to do no more than mention the drugs which can be usefully employed; in giving details of dosage they sometimes err, as, for example, when they recommend $3 \mathrm{~g}$. of chloramphenicol four-hourly for three weeks in the prophylaxis of scrub typhus, and $2.7 \mathrm{~g}$ : (grains 4r) of S.A.T. in the treatment of intestinal schistosomiasis -truly heroic doses! This, however, is but a minor criticism in a work of such all-round excellence, and the reviewer would like to put on record the fact that he could not find one single spelling or printing mistake. This is more than can be said for some of the current books on tropical diseases, and reflects the meticulous care that has been taken in proof-reading and printing.

In its short life of five years this book has rightly established itself as the leading British textbook on the subject of public health in the Tropics.

\section{Adrenergic Mechanisms}

Ciba Foundation Symposium. Editors: J. R. VANE, B.SC., D.PHIL.; G. E. W. WOLSTENHOLME, O.B.E., M.A., M.B., M.R.C.P.; M. O'CONNOR, B.A. Pp. $x x+632$, illustrated. London: J. \& A. Churchill. 1960. 70 .

This Ciba symposium volume is a verbatim account of a two-day meeting arranged by the coordinating Committee for Symposia on Drug Action at the Wellcome Building in London and of a consecutive two-day unscripted discussion held at the Ciba Foundation. The topics which were reviewed and discussed are the formation and inactivation of adrenergic transmitters, storage of catechol amines, the adrenergic neurone, adrenergic mechanisms in man, actions of adrenaline and noradrenaline on the effector cell, mechanism of action of other sympathomimetic amines, central adrenergic mechanisms, and general aspects. Sections of the discussion at the Ciba Foundation which are particularly relevant to papers given at the Wellcome Building have been transferred to the discussions following the latter. The majority of the 46 papers are presented by leading research workers in the form of reviews or summaries of the work carried out in individual laboratories. There is a considerable overlap between contributions to this symposium and those given at a similar symposium on catechol amines held at the National Institutes of Health, Bethesda, Maryland, U.S.A., in October 1958, and published verbatim without discussion in Pharmacol. Reviews, I959, II, 233-566. The discussions, reported in full, are most informative and at times entertaining. Those not working on adrenergic mechanisms will find the chairman's summary by J. H. Gaddum particularly useful.

The book is well presented and its numerous illustrations are clear and well reproduced. The book can be strongly recommended to all who are interested in basic medical sciences.

\section{Synopsis of Pathology}

W. A. D. ANDERSON, M.A., M.D., F.A.C.P., F.C.A.P. Fifth edition. Pp. 876, with 414 illustrations and 4 colour plates. St. Louis: C. V. Mosby Co. London: Henry Kimpton. I960. £3 ros.

The task of encompassing within one volume the whole field of pathology presents such formidable difficulties that we must congratulate Professor Anderson on this new edition of his compact synopsis of pathology. The work of one author, it provides more attractive reading than the larger compilation which Professor Anderson edits. The revision has been thorough, many recently described conditions are included and new concepts of disease are given brief but adequate mention. The lists of references are representative, preference being given to well-known papers, but also to many very recent publications. One criticism is the poor quality of a few of the illustrations of gross specimens. These, often surprisingly of common conditions, detract from the majority, whose abundance and range are welcome. The photomicrographs are excellent.

This enchiridion of pathology is evidently intended for medical students and general practitioners. The up-todate information it contains will extend its usefulness to those who normally turn to a much larger work of reference.

\section{Recent Advances in Pathology}

By various authors. Edited by Professor C. V. HARRISON, M.D. Seventh edition. Pp. xi +459 , with 140 illustrations. London: J. \& A. Churchill. 1960. £2 8 s.

This is an excellent example of a most useful series whose purpose is indicated in the title. This seventh edition, like its predecessor, has so much new material as to constitute a new book. The work deals predominantly with morbid anatomy and histology and compiles much important recent work only available otherwise in widely scattered publications. Professor Harrison is to be congratulated on his own considerable contributions and on the editing of an excellent compilation.

\section{The Evidence for Survival from Claimed Memories of Former Incarnations}

The winning essay of the contest in memory of William James

Ian Stevenson, M.D. Tadworth, Surrey: M. C. Peto. 196r. 2s.

The doctrine of metempsychosis and the belief in survival of the human spirit after death of the material body are as old as history, and have been the occasion of no little wrangling between philosophers and scientists. It is doubtless true that scientific proof and that internal proof upon which the philosopher relies are, like oil and wine, two good things which do not readily mix. 